\title{
BOALA TROMBOEMBOLICĂ LA COPIL (EPIDEMIOLOGIE, ETIOPATOGENIE ŞI DIAGNOSTIC) (I)
}

\author{
Otilia-Elena Frăsinariu, Violeta Ştreangă, Aniela Rugină, Irina Ciomaga, \\ Nistor Nicolai \\ Disciplina Pediatrie, Universitatea de Medicină şi Farmacie „, Gr. T. Popa “, Iaşi
}

\begin{abstract}
REZUMAT
Tromboza este rezultatul unui dezechilibru între două sisteme complexe: hemostaza şi fibrinoliza. Deşi incidența tromboembolismului este mai mică la copii decât la adulți, morbiditatea asociată acestei patologii este semnificativă din punct de vedere clinic. Lucrarea îşi propune o trecere în revistă a principalilor factori de risc importanți în definirea unor strategii eficiente pentru tromboprofilaxia primară la copiii cu risc pentru boala tromboembolică, a criteriilor diagnostice şi a conduitei terapeutice optime, care, până în prezent, au fost în mare parte extrapolate din recomandări pentru tromboembolismul venos (TEV) la adulți.
\end{abstract}

Cuvinte cheie: tromboză, copil, terapie anticoagulantă

\section{INTRODUCERE}

Considerată, clasic, specifică adultului, patologia tromboembolică prezintă o tendinţă în creştere a incidenței în rândul populației pediatrice în ultimele 2 decenii (1-3). Trombozele copilului sunt corelate cu o morbiditate şi mortalitate semnificative, ce includ recurenţa tromboembolismului venos, sindromul post-trombotic, precum şi moartea prin tromboembolism pulmonar masiv (4).

\section{EPIDEMIOLOGIA}

Tromboembolismul venos (TEV) include trom boza venoasă profundă (TVP), de la nivelul membrelor superioare şi inferioare sau de la nivelul vascularizației centrale, tromboembolismul pulmonar (TEP), tromboza venoasă a sinusurilor cerebrale (TVSC) şi tromboza venei renale (TVR). TEV este rar la copil în comparație cu adultul, dar este tot mai des întâlnit ca o complicație a măsurilor terapeutice intensive din bolile letale (5). Incidența TEV la copil nu este bine definită, din cauza numărului mic de studii existente. Datele raportate de Andrew M. şi col. în Canada (6), van Ommen H. şi col. în Țările de Jos (7) şi Stein P.D. în SUA (3) indică o incidență variind între 0,07-0,49 la 10.000 de copii cu vârsta între o lună şi 18 ani sau 5,3-8,7 la 10.000 de copii spitalizați. Un studiu din SUA remarcă însă o creştere a incidenței cu 70\% între 2001 şi 2007, de la 34 de cazuri/10.000 de copii la 58 de cazuri/ 10.000 copii în spitalele terțiare (2). La ora actuală, în România nu există studii care să precizeze incidența şi prevalența acestei boli la copil.

S-au remarcat două vârfuri de frecvență: în primul an de viață şi la adolescență (3). Incidența mai mare la adolescenți se datorează, în parte, trecerii la un profil de coagulare asemănător adulților. TEV la adolescenți este adesea multi-factorial, majoritatea cazurilor prezentând cel puțin 2 factori de risc (FR) la momentul diagnosticului, sugerând necesitatea unei evaluări detaliate pentru FR în această populație (4). La adolescenți, incidența este mai mare la fete decât la băieți (1,49 față de 0,81/10.000 de copii pe an), prezența sarcinii şi utilizarea contraceptivelor orale favorizând această diferență (3).

Majoritatea trombozelor venoase (TV) la copil sunt dobândite. Peste $90 \%$ dintre copiii afectați de tromboze au cel puţin un factor de risc (4). Trombozele spontane sau idiopatice sunt reduse numeric, datele din registrul canadian şi cel olandez arătând că frecvența acestora la copil este doar 2-8,5\% din totalul trombozelor pediatrice, spre deosebire de $40 \%$ la adulți $(7,8)$. În ceea ce priveşte distribuția tipurilor de TEV, studiile au arătat o preponderenţă a TVP şi TEP, cu o incidenţă de 90-96\% din totalul evenimentelor tromboembolice (4). 
Mortalitatea copiilor cu tromboze este 6,4-17\%, dar cel mai adesea este în raport cu patologia asociată (9). Un studiu recent menționează o mortalitate generală de 11,4 la 1.000 de copii/an (10). Mortalitatea corelată direct cu TEV este doar 1,5-2,2\% (7). Riscul de deces scade o dată cu creșterea vârstei, lucru ce poate fi explicat parțial prin faptul că TEV la copiii mici apare adesea în contextul unor boli critice (5).

Tromboembolismul arterial (TEA) are o incidență de 8,5 la 10.000 de copii spitalizați. (11). În Danemarca, s-a raportat o rată a incidenței accidentul ischemic cerebral de 1,33 la 100.000 de persoane/an şi un peak al incidenței sub vârsta de 1 an (1). Majoritatea trombozelor arteriale (TA) la copil sunt iatrogene, secundare unui cateter arterial. De asemenea, studiile recente relevă o incidență de 3,4$11,4 \%$ a TA după cateterizarea cardiacă, vârsta şi greutatea mică fiind semnificativ asociate cu un risc crescut $(11,12)$.

\section{ETIOPATOGENIA BOLII TROMBOEMBOLICE}

Sistemele hemostatic şi fibrinolitic ale copilului sunt sisteme dinamice, în continuă evoluție până la adolescență, prezentând unele particularități față de adult. Concentrațiile plasmatice ale factorilor de coagulare dependenți de vitamina K (II, V, VII, IX, X, XI şi XII) sunt cu 20\% inferioare celor de la adult (3). De asemenea, până la vârsta de 6 ani, concentratiile plasmatice ale plasminogenului, $\alpha 2$ anti-plasminei şi activatorului tisular al plasminogenului (tPA) sunt diminuate în raport cu cele ale adultului. Concentrațiile inhibitorului activatorului plasminogenului (PAI-1) sunt crescute. Antitrombina III şi proteina $C$ sunt semnificativ mai scăzute față de adult pe parcursul întregii copilării, în timp ce valorile proteinei $\mathrm{S}$ ajung asemănătoare adultului la vârsta de 3-6 luni. (13).

Mai mulți factori pot proteja copiii de TE, contribuind astfel la o incidență redusă de-a lungul copilăriei. Dintre aceştia, mai elocvenţi sunt reducerea capacității de generare a trombinei, capacitatea crescută a alfa-2-macroglobulinei de a inhiba trombina, prezența anticoagulanților circulanți la naştere. Există un potențial antitrombotic crescut la nivelul pereților vaselor, copilul prezentând mai rar boli care provoacă leziuni ale endoteliul vascular (diabet, dislipidemii, hipertensiune). Mai mult, copiii sunt mai puțin frecvent expuşi la factorii de risc protrombotic dobândiți (boli maligne, contraceptive orale, terapia de substituție hormonală, sarcina, fumatul, intervenții chirurgicale) (14).

Mecanismul primar pentru dezvoltarea trombozei este considerat triada lui Virchow - staza ve- noasă, lezarea endoteliului vascular şi starea de hipercoagulabilitate -, contribuția fiecărui factor variind în funcție de grupa de vârstă. Statusul hipercoagulant se poate datora unor boli primare, trombofilii sau poate fi secundar altor boli sau tratamente (anticoncepționale, tratamente hormonale, chimioterapie) (15).

Etiologia trombozelor la copil este variată, factorii de risc fiind numeroşi (Tabelul 1). Apariţia trombozei este precipitată cel mai adesea de coexistența mai multor factori de risc.

TABELUL 1. Principalii factori de risc ai trombozelor la copii

\begin{tabular}{|c|c|c|c|}
\hline \multicolumn{4}{|c|}{ Patologie generală cu risc trombotic } \\
\hline \multicolumn{2}{|c|}{$\begin{array}{l}\text { Lupus eritematos sistemic } \\
\text { Boli autoimune } \\
\text { Sindromul antifosfolipidic } \\
\text { Sindrom nefrotic } \\
\text { Purpura trombocitopenică } \\
\text { Talasemia } \\
\text { Boală inflamatorie } \\
\text { intestinală } \\
\text { Insuficiență renală cronică } \\
\text { Maladii metabolice } \\
\text { (homocisteinemia, } \\
\text { hiperlipemie) } \\
\text { Obezitate } \\
\text { Diabet }\end{array}$} & \multicolumn{2}{|c|}{$\begin{array}{l}\text { Sepsis } \\
\text { Deshidratare } \\
\text { Coagularea intravasculară } \\
\text { diseminată (CID) } \\
\text { Sarcina, perioada post-partum } \\
\text { sau post-abortum } \\
\text { Malignitate } \\
\text { Factori medicamentoși } \\
\text { (contraceptive orale, } \\
\text { chimioterapie-asparaginază, } \\
\text { tamoxifen; corticoterapie } \\
\text { prelungită ) } \\
\text { Patologie cardiacă cronică } \\
\text { Patologie hepatică cronică } \\
\text { Intervenție chirurgicală recentă } \\
\text { Traumă sau fractură care } \\
\text { a necesitat spitalizare sau } \\
\text { intervenție chirurgicală }\end{array}$} \\
\hline $\begin{array}{l}\text { Factori de } \\
\text { risc locali în } \\
\text { trombozele } \\
\text { venoase }\end{array}$ & \begin{tabular}{|l|} 
Factori de \\
risc locali \\
tromboze \\
arteriale
\end{tabular} & & $\begin{array}{l}\text { Factori de risc } \\
\text { ereditari }\end{array}$ \\
\hline $\begin{array}{l}\text { Cateterele } \\
\text { venoase } \\
\text { centrale } \\
\text { Malformații } \\
\text { venoase } \\
\text { Inflamație } \\
\text { perivenoasă } \\
\text { secundară unei } \\
\text { infecții } \\
\text { Compresiune } \\
\text { venoasă (aparat } \\
\text { gipsat, fractură) }\end{array}$ & $\begin{array}{l}\text { Catetere } \\
\text { arteriale c } \\
\text { Arterita T } \\
\text { Boala Kan } \\
\text { Arterele } \\
\text { organelor } \\
\text { transplan } \\
\text { Anevrism } \\
\text { gigante d } \\
\text { coronare } \\
\text { Valve carc } \\
\text { mecanice }\end{array}$ & $\begin{array}{l}\text { lentrale } \\
\text { akayasu } \\
\text { Jasaki } \\
\text { tate } \\
\text { ele } \\
\text { e artere }\end{array}$ & $\begin{array}{l}\text { Deficit de antitrombină } \\
\text { (AT) III } \\
\text { Deficit de proteina C } \\
\text { Deficit de proteina S } \\
\text { Mutația } 20210 \text { a } \\
\text { protrombinei } \\
\text { Mutația G1691A a } \\
\text { factorului V } \\
\text { Mutația metil- } \\
\text { tetrahidrofolat-reductazei } \\
\text { (MTHFR) } \\
\text { Hipoplasmogenemie } \\
\text { Displasminogenemie } \\
\text { Defect de eliberare al } \\
\text { activatorului tisular al } \\
\text { plasminogenului } \\
\text { Creșterea lipoproteinei A }\end{array}$ \\
\hline
\end{tabular}

Prezența unui CVC este considerată cea mai frecventă cauză asociată TE. Tromboza corelată cu un cateter constituie $90 \%$ din toate evenimentele trombotice din primul an de viață şi până la două treimi din totalul TEV la copii $(6,7)$. Cele mai multe TV asociate unui CVC se produc la nivelul siste- 
mului venos superior, datorită localizării CVC pe vena jugulară sau subclaviculară. În majoritatea cazurilor de tromboze arteriale există o patologie subiacentă. Accidentele tromboembolice arteriale nedatorate cateterelor au ca şi cauză fie o afecțiune congenitală (hiperhomocisteinemie, hiperlipidemie primitivă, cardiopatie), fie una dobândită (Tabelul 1).

Trombofilia ereditară este întâlnită la $10-59 \%$ dintre copiii cu tromboză venoasă idiopatică $(1,16,17)$. Cele mai semnificative afectiunii ereditare cu efect protrombotic se regăsesc în tabelul I. Studiile efectuate la copiii cu TEV au indicat o incidenţă a principalelor anomalii ereditare de: 4,7-13\% prezența Factorul V Leiden; 2,3-3\% - mutația genei protrombinei; $1-1,2 \%$ deficit de proteină $\mathrm{S}$; $1 \%$ - deficit de AT III; 0,6-1\% deficit de proteină C; $2,6 \%$ - defecte combinate; $7,5 \%$ creşterea concentrației plasmatice a lipoproteinei A $(16,17)$. O metaanaliză pe 22 de studii observaționale a relevat o asociere semnificativă a trombofiliei cu apariția atacului ischemic cerebral şi trombozei sinovenoase cerebrale, cu o cotă a riscului (odds ratio) variind între 2,43 în cazul prezenței mutației genei protrombinei până la 9,31 pentru deficiența de proteină $C$ şi 11,86 în prezența a cel puțin 2 FR (18).

Trombofilia constituie un factor de risc suplimentar şi nu factor unic declanşator în patologia trombotică. Riscul trombotic al unui copil sănătos care are un singur defect trombofilic este scăzut, factorii de risc dobândiți având o contribuție majoră. Screening-ul pentru trombofilie la copiii sănătoşi cu vârsta mai mică de 15 ani, care fac parte din familii cu tulburări trombotice moştenite, nu este justificată, deoarece riscul real de TEV este scăzut (19). Prezența trombofiliei se corelează cu o vârstă timpurie de debut a TE şi cu recurențe frecvente. TEV recurent se asociază cu toate tulburările de coagulare moştenite, cu excepția nivelurilor crescute ale lipoproteinei A (20).

Rezistenta la proteina $\mathrm{C}$ activată (RPCa) apărută ca urmare a mutației factorul V Leiden este considerată cea mai frecventă predispoziție ereditară la tromboză, care se regăseşte la $3-8 \%$ din populaţie (15). Transmisia bolii este autosomal dominantă (AD). Riscul de apariţie a trombozei este de 7-8 ori mai crescut, comparativ cu populația generală, la cazurile heterozigote, acest risc crescând de până la 80 de ori în cazurile homozigote. Cel mai frecvent se manifestă prin TV, tromboembolism recurent, incluzând TVC, avorturile repetate fiind semnalate în perioada de adult (15). RPC se asociază frecvent $\mathrm{cu}$ alte predispoziții genetice (deficiența proteinei $\mathrm{C}$, a proteinei $\mathrm{S}$, a antitrombinei III).
Proteinele $\mathrm{C}$ şi $\mathrm{S}$ sunt proteine vitamino-K dependente care inactivează factorul Va şi factorul VIIIa. Incidența în populația generală este de 0,14 $0,5 \%$ (15). Transmisia deficienței de proteină $\mathrm{C}$ sau $\mathrm{S}$ este AD. Cele mai frecvente manifestări ale deficienței de proteină $\mathrm{C}$ sunt TV la nivelul membrelor inferioare, venelor iliofemurale, venelor mezenterice, TVC, purpura fulminans la nou-născuții homozigoți, necroze cutanate induse de tratamentul cu warfarină la bolnavi heterozigoți. TA apar mai frecvent la vârsta adultă. Deficitul de proteină S se manifestă prin TVP, tromboflebită superficială şi TEP.

Deficiența de antitrombină III se transmite AD, incidența în populația generală fiind de $0,02-0,17 \%$ (15). Forma homozigotă se manifestă dramatic, cu tromboză extinsă încă din primele ore de la naştere şi deces. Riscul trombozelor este estimat la $50 \%$ (16). În bolile hepatice, în SN, CID, tratamentul cu contraceptive orale, poate apărea o deficiență dobândită de ATIII (15). Deficiența de AT este cel mai frecvent asociată cu TV.

Anticorpii antifosfolipidici (cardiolipina, anticorpii lupici anticoagulanți) sunt asociați cu sindromul de hipercoagulabilitate. Incidența TE la pacienții cu LES este între 9,2-17\% (7).

Principalele complicații ale tromboembolismului sunt reprezentate de trombozele recurente, sindromul post trombotic, sângerări şi deces. Nivelurile plasmatice crescute de factor VIII şi/sau Ddimeri şi persistența acestor valori după terapia anticoagulantă standard indică un prognostic prost la copii cu tromboză (21). Rata de recurenţă este de 4,8\% la copii fără FR genetici, 17,6\% în prezența unui FR ereditar şi creşte la 50\% în prezența a mai mult de 2 FR ereditari (20). Sindromul postrombotic este caracterizat printr-o insuficiență venoasă cronică, simptomatologia variind de la edem la durere cronică şi ulcerații ale membrului afectat. Datele registrului canadian relevă o prevalență de 21$25 \%$ la copiii cu TV (22).

\section{DIAGNOSTIC}

Diagnosticul trombozelor este în primul rând clinic, urmând a fi completat de investigațiile biologice şi explorările paraclinice, în funcție de orientarea către o anumită etiologie.

$\mathrm{O}$ anamneză bine condusă stă la baza elucidării unei posibile cauze trombotice, prin aprecierea factorilor de risc trombotic. Manifestările clinice sunt variate şi depind în primul rând de localizarea şi de dimensiunea trombusului. În cazul copiilor, semnele şi simptomele pot mima sau se pot suprapune peste cele ale altor patologii mult mai frecvente şi 
mai uşor de suspicionat la prima evaluare. De asemenea, simptomele pot lipsi sau pot fi atât de discrete încât să nu fie evidențiate de pacient sau chiar în cadrul unui examen clinic. Incidența TEV corelat cu un CVC asimptomatic este estimată la 66\% din totalul copiilor cu CVC şi până la $40 \%$ dintre pacienții oncologici pediatrici (22).

În trombozele venoase profunde se poate obiectiva tumefiere dureroasă şi eritem al unui membru, de obicei inferior. La membrul inferior poate fi prezent semnul Homans (durere la dorsiflexia piciorului pe gambă) şi cordon dureros la palpare. La membrul superior, dacă tromboza se întinde la vena cavă superioară (VCS), apare sindrom cav superior cu: edem în pelerină, chemozis, edem facial, circulație venoasă colaterală şi cianoză în teritoriul VCS. Mai mult, pot apărea chilotorax sau chilopericard (23). TEV asociat unui CVC simptomatic se poate manifesta prin pierderea repetată a permeabilității CVC, sepsis, circulație colaterală la nivelul tegumentelor. În trombozele arteriale ale membrelor apare diminuarea pulsului, durere, temperatură locală scăzută şi, progresiv, membrul îşi schimbă culoarea în violaceu spre negru.

În contextul unei dureri toracice violente (frecvent retrosternală sau precordială), a dispneei marcante, cianozei, tahicardiei, sincopei, se poate suspiciona tromboembolismul pulmonar. Un simptom important, care apare la toate categoriile de vârstă pediatrică, este tahipneea persistentă, fără cauză evidentă (22).

Trombozele arteriale şi venoase cerebrale la nou-născut pot fi asimptomatice, iar la copil se pot manifesta prin cefalee, vărsături, convulsii, tulburări ale stării de conştienţă, tulburări neurologice focale, hemipareză.

În trombozele de vene renale, examenul clinic poate evidenția mase abdominale la palparea profundă, hematurie macroscopică, însoțită sau nu de oligoanurie, proteinurie sau HTA. Factorii de risc care se asociază cu TVR sunt SN, LES, transplantul renal. În cazuri foarte rare, când trombul este localizat în teritoriul splahnic (vene porte, splenice sau mezenterice), tromboza se manifestă prin dureri abdominale, semne de insuficienţă hepatică, hemoragie digestivă sau poate fi asimptomatică. Substratul favorizant îl constituie neoplaziile localizate în aceste zone, ciroza hepatică, splenectomia, infecțiile, prezența Ac antifisfolipidici (24).

În cazuri grave, cum sunt bolile mieloproliferative cronice, CID, necroze post-antivitamine K, poate apărea o tromboză extinsă arterio-venoase, cu manifestări severe, până la necroza cutanată întinsă sau necroza membrelor, cu prognostic nefavorabil.
Trombofilia ereditară se suspectează în cazul unor tromboze recurente, în lipsa unor factori favorizanți, în prezența unui istoric familial de tromboze.

Paraclinic există mai multe metode pentru confirmarea diagnosticului de tromboză şi pentru aprecierea întinderii şi severităţii acesteia. $\mathrm{Nu}$ există teste de laborator specifice disponibile pentru diagnosticarea TE. Anemia, trombocitopenia sau fragmentele hematice pot sugera un CID. Pentru evaluarea statusului coagulant se recomandă investigarea timpului de coagulare, a timpului de protrombină, a activității de protrombină, a timpului parţial de tromboplastină (PTT), a timpului parțial de tromboplastina activată (APTT), a INR-ului şi fibrinogenul. Trombozele acute sunt însoțite de creşterea nivelurilor plasmatice ale unor factori de coagulare (fibrinogen, V, VII, VIII, FvW, X). Se investighează prezența anticorpilor antifosfolipidici (Ac anticardiolipină, Ac anti $\beta 2$-glicoproteina 1) şi a anticoagulantului lupic.

Pentru stabilirea etiologiei trombofilice, anomaliile care trebuie căutate de primă intenție sunt: mutația F V Leiden şi mutaţia G20210 a protrombinei, deficitul de AT III, proteină C şi proteină S, hiperhomocisteinemia, creşterea lipoproteinei A. În absența acestor anomalii, dacă suspiciunea unei anomalii ereditare de hemostază persistă, se vor investiga factorii IX, XI şi prezența unei disfibrinogenemii. Nivelurile plasmatice ale factorilor anticoagulanți (antitrombina III, proteina C, proteina S) pot fi afectate de răspunsul de fază acută care însoțeşte procesul trombotic sau de terapia anticoagulantă (25).

Nivelul seric crescut al D-dimerilor în prezența unei tromboze acute este datorat activării simultane a coagulării şi fibrinolizei. Dozarea D-dimerilor este o metodă foarte sensibilă de diagnostic, dar puțin specifică, D-dimerii putând fi crescuți şi în patologia inflamatorie, infecțioasă, tumorală, traume, post-chirurgie, sarcină, hepatopatii. Un nivel normal exclude posibilitatea unei TVP sau a unei TEP acut. Dozarea lor este foarte utilă în supravegherea bolii tromboembolice pentru decelarea eventualelor recidive (26).

Metodele de diagnostic imagistice pentru stabilirea sediului şi extensiei procesului trombotic se bazează pe tehnici invazive (venografie) sau noninvazive (echo Doppler, CT scan). Ecografia Doppler este utilizată ca instrument de diagnostic primar, pentru a confirma tromboza la adulți şi copii, rezultatele putând fi comparabile cu angiografia de contrast. În vasele trombozate, semnalul Doppler este absent, iar lumenul nu poate fi comprimat. Ecogra- 
fia permite distincția între o tromboză recentă şi una veche (25). Factorii care ar putea interfera cu această metodă imagistică la vârsta pediatrică includ: diametrul mic al vaselor, presiunea scăzută a pulsului, iar prezența unei linii venoase la locul trombusului face dificil de comprimat vena (15). Ecografia Doppler este recomandată pentru evaluarea inițială a trombozei la nivelul extremităților inferioare. $\mathrm{Cu}$ excepția venelor jugulare şi axilare, diagnosticul trombozei în sistemul venos superior cu ajutorul ecografiei Doppler are sensibilitate redusă, cu rezultate fals negative (23).

Angiografia/venografia cu contrast este considerată standardul de aur pentru diagnosticul trombozelor la copil. Astăzi este rar folosită deoarece este o tehnică invazivă, dureroasă, iar abordul venos periferic la copil este dificil de obținut (25). În cazul în care suspiciunea clinică de tromboză venoasă este mare şi tehnica ecografică Doppler este negativă sau echivocă, se poate efectua angiografie
CT sau RMN pentru confirmarea trombozei. CT-ul craniocerebral $\mathrm{cu}$ contrast este util pentru detectarea trombozei sino-venoase, dar RMN-ul este mai sensibil în detectarea precoce a unui accident cerebral ischemic (25).

Scintigrafia de ventilaţie-perfuzie este un test diagnostic standard utilizat pentru suspiciunea de TEP, dar la copii a fost înlocuită la scară largă cu angiografia CT/RMN (25). Corelația dintre nivelul crescut al d-dimerilor şi un aspect modificat la scanarea imagistică confirmă diagnosticul de TEP. Important de menționat este faptul că, la adolescentele gravide, scintigrafia pulmonară este de preferat față de angio-CT, cantitatea de radiații absorbită de făt fiind mai redusă (26). Electrocardiograma, radiografia toracică şi evaluarea gazelor arteriale pot fi utilizate pentru evaluarea suspiciunii de TEP, indicându-ne absența altor patologii, dar nu pot confirma sau exclude prezența trombozei. 